\title{
Control of Insect Vectors in the Japanese Empire: Transformation of the Colonial/Metropolitan Environment, 1920-1945
}

\author{
Akihisa Setoguchi \\ Received: 22 January 2007 / Accepted: 4 December 2007 / \\ Published online: 6 May 2008 \\ (C) National Science Council, Taiwan 2008
}

\begin{abstract}
This paper discusses the establishment of insect pest control in Japan for preventing disease transmission. In the late nineteenth century, after the establishment of tropical medicine in Great Britain, many insects were recognized as vectors. However, it was only after the 1920 s that the control of insects became a social agenda in Japan. In colonial Taiwan, the transformation of the environment was initiated to exterminate the mosquito vectors of malaria. Almost simultaneously, in the metropolises of the Japanese mainland, extermination of flies was initiated through mass mobilization. This paper compares the scientific framework of the colonial and metropolitan context and throws light on the participation of parasitologists, entomologists, and bacteriologists in studying insect vectors. It also examines the mobilization of scientists during the Asia Pacific War and how it changed the framework of studies related to insect-borne diseases. Finally, I discuss the fact that mobilization under conditions of war rendered post-war control of insect vectors.
\end{abstract}

Japanese Abstract 本論文は、近代日本における「衛生害虫の制御」が、医 学研究の枠組みをいかに変容させ、さらには人間と環境の関係をどのよう に組み換えたのか検討するものである。19世紀末の英国で成立した熱帯医 学は、様々な病気が昆虫によって伝播されることを明らかにした。しかし これらの医学的な知見が、直ちに「衛生害虫の制御」に結びついたわけで はない。日本では1920年代に入って2つの場所で「衛生害虫の制御」が試み られるようになる。まず植民地統治下の台湾においては、マラリアを媒介 するアノフェレス蚊を根絶するため、土木工事によって環境を改変する事 業がはじまった。一方、大阪・東京などの主要都市では、市民を動員した 大規模なハ工の駆除が行なわれるようになる。本稿では、これらの事業に 寄生虫学・昆虫学・細菌学などがどのようにかかわったのか検討し、植民 地と都市における医学的な枠組みの違いを明らかにする。さらにアジア太

\footnotetext{
A. Setoguchi $(\bowtie)$

Graduate School of Economics, Osaka City University, Osaka, Japan

e-mail: asetoguchi@gmail.com, akihisa.setoguchi@nifty.com
} 


\section{平洋戦争がはじまると、衛生害虫をめぐる医学研究の枠組みは、再び大きく 变容していくことになる。最後に、戦後の日本では戦前期の研究蓄積を基盤 として、人間と衛生害虫の関係が大きく組みかえられたことを指摘する。}

Keywords Malaria - Medical zoology · Metropolitan public health · Military mobilization $\cdot$ Medical entomology

\section{Introduction}

Isabella Bird (1831-1904), a British woman who traveled to northern Japan in 1878, repeatedly complained that there were too many insect pests in the country. During her stay in a small village, she remarked "[b]eetles, spiders, and wood lice held a carnival in my room after dark ... and fleas rendered sleep impossible." Even in large cities such as Niigata, she reported being attacked by a "myriads of flying, creeping, jumping, running creatures, all with power to hurt" (Bird 1880). She was not the only person who encountered the problem of insect pests in Japan. Edward Morse (1838-1925), the founding professor of the Department of Zoology at the University of Tokyo complained that "[f]leas are the one fearful nuisance of the country" (Morse 1917). Charles Marlatt (1863-1954), an American entomologist who came to Japan in the summer of 1901, was awakened by a burning pain in his elbow one night. He found "hundreds of mosquitoes" swarming to bite him (Marlatt 1953). In those days, although the Japanese people used mosquito nets and insecticide powders in order to escape from mosquitoes and flies, they never tried to exterminate them. These insects were so abundant, that it seemed impossible to eradicate them. Furthermore, the Japanese people did not recognize these insects as harmful transmitters of pathogens. ${ }^{1}$

Western medicine had also not paid much attention to disease-transmitting insects prior to the late nineteenth century. It was only after the 1870 s that many tropical diseases, such as filariasis, malaria, and sleeping sickness, came to be accepted as insect-borne diseases. One result was the establishment of 'tropical medicine' in the late nineteenth century Great Britain, which John Farley has argued was centered on parasitological research and had a different institutional situation to the existing medical disciplines such as bacteriology (Farley 1992). In addition, Shang-Jen Li has shown that Patrick Manson's tropical medicine was essentially field-based natural history, with a focus on vectors and their ecology that was distinct from laboratorybased bacteriology (Li 2002). ${ }^{2}$

How did the new profile of insect vectors change the framework of medical research in Japan? Although many historians have discussed tropical medicine in Japan with considerable attention, not many have dealt with the disciplinary framework of medical research. ${ }^{3}$ This paper examines how parasitologists, entomologists, and bacteriologists participated in the study of insect vectors.

\footnotetext{
${ }^{1}$ Even in the Western countries, flies were not considered chiefly harmful insects before the late nineteenth century; see Rogers (1989).

${ }^{2}$ On history of tropical medicine, see also Worboys (1976, 1993, 1996).

${ }^{3}$ For information on the comprehensive historical study of malaria research in the Japanese Empire; see Iijima (2005).

型 Springer
} 
The other theme of this paper is the ecological result of insect vector studies in Japan. Recently, the ecological aspect of medical research has begun to be reviewed from the viewpoint of environmental history. For example, Helen Tilley has discussed how entomological research on the vector of African trypanosomiasis led to the emergence of ecological understanding of the disease in the early twentieth century (Tilley 2004). Thus, research on insect-borne diseases lies at the border between medical and environmental history. This paper also explores how the new frameworks of Japanese medical research changed the relationship between people, diseases, and their environment.

It was after the Meiji Restoration that the new government began to introduce Western science, technology and medicine. Medicine was based on the German model, where bacteriological research was in full flourish, while entomology was established in agricultural colleges and agricultural experimental stations by the 1890 s. As they were in separate institutions, it is unsurprising they did not work together until the 1920s, when disease-transmitting insects were placed on the social agenda in two areas: colonial Taiwan and the metropolises in the Japanese mainland. However, the medical frameworks in these two areas were rather different. In this paper, I first compare the medical research in the colonial and metropolitan contexts in the 1920s, and then, I discuss the strong impact of the Asia Pacific War on research on insect vectors in both colonial Taiwan and the Japanese mainland.

\section{Colonial Taiwan and Mosquitoes: Medical Zoology and Transformation of the Environment}

Japan encountered the first outbreak of malignant malaria in 1874, during its invasion of Taiwan and it resulted in high mortality against soldiers. There were more than 500 casualties, approximately 10 percent of the Japanese soldiers present. Although the vivax malaria had been prevalent on the Japanese mainland for many years, it was a different type of disease from that found in the tropical areas. The latter type of malaria, which was caused by Plasmodium falciparum, was considerably more severe than the former, often proving fatal. Twenty years later, during the war to occupy Taiwan in 1895, almost 27,000 Japanese soldiers suffered and more than 4,000 soldiers died from the disease - a toll that was almost 30 times greater than the number dying in combat. After the occupation, the Japanese government established the Medical School of the Government General of Formosa (総督府医学校) in 1897 and this became the base for research on the diseases of the island (Morishita 1976, Chapter 1).

Japanese doctors started investigating mosquito vectors as early as 1899 , one year after Ronald Ross's discovery of the mechanism of malaria transmission. In that year, Horiuchi Tsuguo (堀内次雄, 1873-1955), a doctor at the Medical School of the Government-General of Formosa, visited Nawa Entomological Laboratory (名和 昆虫研究所) in Gifu City to obtain mosquito larval specimens (Oda 1974; Nawa 1899). Nawa Entomological Laboratory was a semi-public institute founded by Nawa Yasushi (名和靖, 1857-1926), who was an agricultural entomologist also interested in medical entomology (Setoguchi 2004). In the same year, the Government-General of Formosa established the Committee on Taiwanese Endemic 
Diseases and Epidemics (台湾地方病及伝染病調査委員会) and started a scientific study of malaria. Kinoshita Kashichirô (木下嘉七郎, 1872-1908), one of the members of the Committee, intensively studied the all the Anopheles species of mosquito in Taiwan. In the early twentieth century, based on these researches and that in many other countries, avoiding mosquito bites was recommended as the way to prevent malarial infection in the Taiwanese army (Tsuzuki 1902).

In 1909, the government established the Institute of the Government-General (総督府研究所) for public health research. ${ }^{4}$ In 1914, a parasitologist, Koizumi Makoto (小泉丹, 1882-1952), came to the Institute for malaria research and established a Laboratory of Medical Zoology (医動物学). Koizumi had graduated from the Zoological Department at the University of Tokyo, where many parasitologists studied under Iijima Isao (飯島魁, 1861-1921), who had studied parasitology and morphology under Rudolf Leuckart (1822-1898) at the University of Leipzig. In those days, most parasitologists in Japan were students of Iijima, and therefore, Japanese parasitology started as a part of zoology rather than as a medical discipline.

What then, was the character of Koizumi's "medical zoology"? On the Japanese mainland, there was no corresponding institute, furthermore, there were no parasitological laboratories in the medical institutes either. Although there were several parasitologists, they were affiliated to the laboratories of pathology or hygiene. The only exception was the laboratory in Kitasato Shibasaburo's (北里柴三郎, 1852-1931) Institute of Infectious Diseases (伝染病研究所), which had been founded in 1902 by Miyajima Mikinosuke (宮島幹之助, 1872-1852), another student of Iijima. ${ }^{5}$ Koizumi had also worked under Miyajima before he went to Taiwan.

Koizumi's "medical zoology" had a broader perspective than just parasitology. Although Koizumi's educational background was protozoology, he was also interested in the intermediate hosts of these parasites. During the bubonic plague outbreak in Kobe in 1907, Koizumi undertook research on fleas transmitting the disease (Morishita 1988). ${ }^{6}$ In Taiwan, he worked strenuously to clarify taxonomy and the ecological distribution of Anopheles mosquitoes, which culminated in 1921 with the publication of The Preventive Medicine on Mosquitoes in Taiwan (Koizumi 1921). Therefore, Koizumi's medical zoology included not only parasitology but also research on insect vectors of human diseases. It was an ecological study of the relationship between human beings, parasites, and disease-transmitting insects.

Although Koizumi's medical zoology included entomological research, his laboratory work laid greater emphasis on parasitology. Morishita Kaoru (森下薰, 1896-1978), who succeeded Koizumi in 1923, was also a parasitologist, and pursued the same career path. He was also a student of Iijima and worked at Kitasato's Institute of Infectious Diseases, but he gave a greater impetus to entomological research than Koizumi. In 1932, he employed an entomologist, Ômori Nanzaburô (大森南三郎, 1905-1988), an agricultural entomologist who had studied at Kyoto University. He worked in Morishita's laboratory on insect vectors

\footnotetext{
${ }^{4}$ This institute was renamed as Central Institute of Governor General (台湾総督府中央研究所) in 1921.

${ }^{5}$ Miyajima became a founding professor of parasitology at Keio University in 1920 . For the biography of Miyajima, see Miyajima (1943).

${ }^{6}$ Koizumi is also a famous historian on evolutionary thought. The relationship between his evolutionary thought and the medical research remains to be explored.
} 
and in 1939, 2 years after the establishment of the Faculty of Medicine at Taihoku Imperial University, Morishita and Omori shifted to the Laboratory of Hygiene as a professor and an associate professor, respectively (Morishita Koru kyôju taikan kinen jigyô jikkô iinkai 1961). ${ }^{7}$

However, entomologists were never able to replace parasitologists. There is an interesting anecdote that indicates the relationship between parasitologists and entomologists in colonial Taiwan. Shiraki Tokuichi (素木得一, 1882-1970), a leading entomologist, had once tried to establish an independent medical entomology laboratory at Taihoku Imperial University. He had a special interest in medical entomology and wrote several research papers on mosquitoes before Koizumi's arrival in Taiwan. However, his proposal was rejected because Taihoku Imperial University decided that medical zoology was already well equipped to deal with malaria research (Shiraki 1969).

How then, did medical zoologists contributed to malaria control practice in colonial Taiwan? In the early twentieth century, two methods were adopted to manage malaria: the anti-mosquito and anti-parasite methods. One of the most prominent supporters of the former method was Ronald Ross, who organized the "Mosquito Brigade" and insisted that the extermination of mosquitoes was the best method to control malaria (Worboys 1988). However, the anti-mosquito method was not very well-received. Even in the 1920s, the Malaria Commission of the League of Nations was skeptical about the method because rapid extermination of mosquitoes appeared too optimistic. The other method, the "anti-parasite method," which involved the control of malaria by attacking the parasite using drugs, was more common (Evans 1989).

The Government-General of Formosa began its programs for malaria control in the 1910s, a decade after the occupation. Back then, the government had to deal with a severe epidemic of bubonic plague that spread throughout East Asia in the early twentieth century (Iijima 2005). In 1909, a Conference on Malaria Control (マラリ ア防遏会議) was organized to discuss the control of malaria in Taiwan and initiated the adoption of extensive anti-malaria measures. As many historians have argued, this conference agreed to adopt "anti-parasite methods," a method that had been more common in German medicine rather than Anglo-American medicine. Since Germany was a model for Japanese medicine after the Meiji Restoration, Taiwan also adopted the anti-parasite method for the control of malaria (Iijima 2005, Chapter 1; Wakimura 2002; Ku 2004).

Anti-parasite measure were officially inaugurated in 1913, when the GovernmentGeneral enacted the Law on Malaria Control Practice (マラリア防遏規則). According to this regulation, malaria control measure began in 12 control areas; a number gradually increased to around 200. In these areas, citizens were compelled to undergo blood tests and those found to have the malarial parasite in their blood were required to take drugs such as quinine (Morishita 1976).

The Government-General gave rather little attention to the anti-mosquito method; however, the government recommended citizens to use mosquito nets. In addition, in 1911, the government introduced the topminnow, a fish predator of mosquitoes from

\footnotetext{
${ }^{7}$ For medical entomologists in Taiwan, see Chu (2005).
} 
Hawaii. Anti-mosquito methods were encouraged more strenuously after 1919, when the government amended the Rules for Operation of the Law on Malaria Control Practice (マラリア防遏規則施行規則). This amendment specified that Anopheles mosquitoes were to be exterminated by destroying the habitats through civil engineering practices. Drainage canals, water pools, and other breeding places of mosquitoes were ordered to be cleaned or even filled. Bamboo thickets, another habitat, were also ordered to be cut down and cleared (Fig. 1). In Taihoku State (台北州), for example, releasing topminnow, a predator of mosquitoe larva, was encouraged. In Takao State (高雄州), "malaria controlling police," that monitored the habitats and numbers of mosquitoes, was established (Taiwan sôtokufu keimu kyoku eisei ka 1932). In addition, many Taiwanese were mobilized for the transformation of their environments to exterminate mosquito vectors.

However, as $\mathrm{Ku}$ Ya-wen demonstrated, this method was unpopular among the indigenous Taiwanese $(\mathrm{Ku}$ 2004). Although they were forced to clean up habitats, they considered it to be a hopeless effort because of the difficulty of extermination. In addition, bamboo thickets had an important part of place in their culture, and they were reluctant to cut them down. Koizumi criticized the anti-mosquito methods, in an article published in 1928, he stated that since the power of nature was considerable, the control of mosquitoes through civil engineering techniques would be difficult. He also said that releasing topminnows was also unlikely to succeed, because it had failed in Europe (Koizumi 1928). As a field biologist, he was familiar with the fact that transforming the entire environment would not be an easy task.

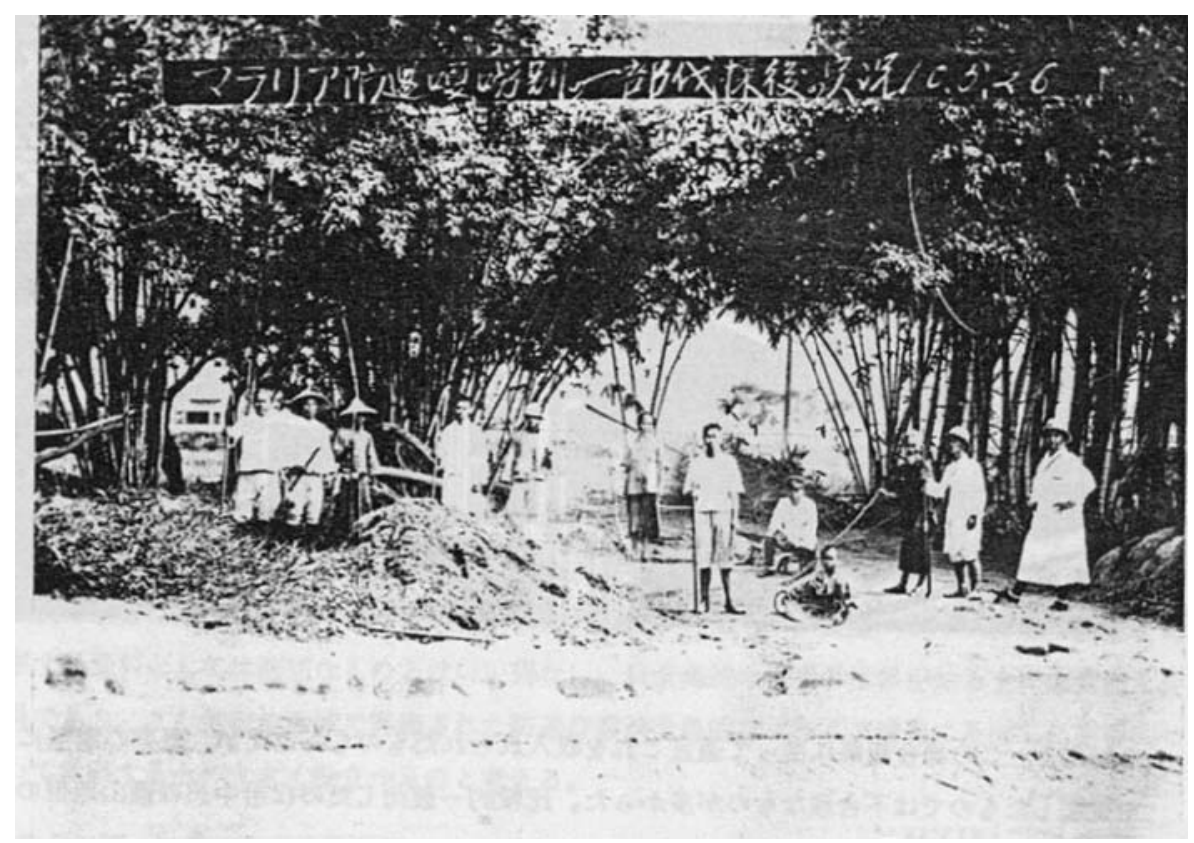

Fig. 1 Bamboo cutting in Taihoku State. From Morishita Kaoru, Mararia no ekigaku to yobô, (Kikuya shobô, 1976) 
To sum up, medical zoology in Taiwan was a field-oriented discipline that included both parasitology and entomology. However, parasitology received greater attention due to adopting anti-parasite methods. Although the colonial government attempted to exterminate insect vectors in the 1920s, mobilization of citizens failed and the transformation of the environment was not successful in Taiwan.

\section{Metropolises and Flies: Public Health through the Mobilization of Citizens}

While colonial Taiwan was dealing with the transformation of the environment, disease-transmitting insects were coming on the social agenda on the Japanese mainland. Rural areas in Japan witnessed many insect-borne diseases before World War II; for example, vivax malaria, which was a different type from the malaria in Taiwan. Filariasis was also prevalent in almost every area of Japan, except Hokkaido. In addition, there were some endemic diseases, such as the tsutsugamushi disease, in northern Japan. In the late nineteenth century, many medical doctors began studying these diseases; however, the Japanese government never attempted to control these diseases by exterminating the insect vectors.

The first insects associated with disease were the flies in metropolitan areas. In Western medicine, it was American doctors and entomologists who highlighted the role of flies as transmitting diseases. However, the diseases carried by flies were different to those transmitted by mosquitoes. Mosquitoes transmit malaria, filariasis, and other tropical diseases, caused by parasitic pathogens. In contrast, flies spread bacteriological diseases such as cholera and typhoid fever, and are sometimes referred to as "mechanical vectors," in order to distinguish them from "biological vectors" such as mosquitoes. In the early twentieth century, most British scholars of tropical medicine worked exclusively on biological vectors, a situation quite different to that in America.

During the Spanish-American War, the American Army suffered a severe outbreak of typhoid fever. In August 1898, a research team was appointed, headed by Walter Read (1851-1902), who later became famous as a co-discoverer of the mosquito vector of yellow fever. The team submitted a report that insisted that the outbreak was partly due to the transmission of pathogens by flies (Rogers 1989). This finding led many entomologists to studying flies. They became "medical entomologists," who studied both mosquitoes and flies. For example, Leland O. Howard (1857-1950), the chief entomologist of the US Department of Agriculture, claimed that in addition to typhoid fever, cholera, dysentery, and diarrhea, and even tuberculosis may be transmitted by flies (Howard 1912; see also Geong 2001). As a result, many cities in the United States started "Anti-Fly campaigns" in order to educate the citizens on controlling harmful insects (Howard 1912; Geong 2001; McClary 1982).

Similar to the scenario in the US, in Japan flies were also found to be responsible for an outbreak of diseases in the Army. However, the outbreak in the Japanese Army was not of typhoid fever but cholera. In the summer of 1902, Tsuzuki Jinnosuke (都築甚之助, 1869-1933), a medical surgeon in the Imperial Army, was dispatched to Tianjin, where there was an outbreak of cholera. Almost 1,300 people were infected in 2 months, and several deaths of Japanese soldiers were reported. 
Tsuduki suspected flies to be the transmitters, and in experiment he found on a Petri dish on which flies had walked around, the pathogen of cholera (Tsuzuki 1903, 1904; Fukami 1931). It must be noted that it was the Army in China and not on the Japanese mainland that found flies as a threat to their health. Tsuzuki stated, "There are incredible amounts of flies in Northern China. Even with window screens and curtains on the doors, they come in with people. ... Native people never pay attention to these creatures" (Tsuzuki 1903). Tsuzuki observed that Asians, in a manner similar to the Westerners who came to Japan in the early Meiji period, linked flies with "uncivilized" people.

The idea of flies as transmitters of cholera emerged on the Japanese mainland in the 1910s. Cholera had frequently brought severe epidemics in Japan during the 1870 s and 1880 s, but its incidence decreased in the early twentieth century. In the late 1910s, Japan experienced what was the last of several epidemics of cholera, in which flies were condemned as dangerous creatures. In 1916, when cholera spread from Yokohama, the Metropolitan Police Office of Tokyo announced that citizens should try to completely eliminate flies. In the following year, the Department of Interior also urged citizens to exterminate flies. Finally, in 1922, the government amended the Law on the Prevention of Infectious Diseases (伝染病予防法) to mandate the control of harmful insects. ${ }^{8}$

In the 1920s, the extermination of flies became a social movement in the metropolises. In July 1920, the Osaka Prefectural Public Health Society (大阪府衛 生会), a semi-governmental organization that aimed at improving hygiene, held the “Swat the Fly Day” (蠅取りデー) to exterminate flies in the city. They held a parade in the city announcing "Get rid of flies that transmit cholera!" (Osaka fu eiseikai 1992). It became a mass event in Tokyo after the Great Kanto Earthquake of 1923, when many refugees were forced to live in dirty shacks in unhygienic environments. Goto Seiko (後藤静香, 1884-1969), a philanthropist, announced a reward of one sen (1/100 yen) for each exterminated fly. ${ }^{9}$ This campaign was taken further by the municipal government of Tokyo, which organized a "Swat the Fly Day" every summer, urging citizens to collect flies. In most cases, flies were exchanged for money and coupons, and citizens competed to collect more flies than the others. As a result, more than 100 million flies were collected throughout the city every summer (Tsutsumi 1928). ${ }^{10}$

Why were the citizens so eager to exterminate flies? What did the "Swat the Fly Day" imply in the contemporary framework of medical research? An important point is that the 1920 s was a turning point for the Japanese metropolises. The migration of the population toward cities brought noise pollution, air pollution, and problems associated with sewage and garbage disposal (Narita 2003). The pattern of diseases also changed. In those days, the public health focus had shifted from the prevention of severe epidemics to maintaining healthy and hygienic cities, and as a part of this new agenda, known as

\footnotetext{
${ }^{8}$ Keishichô shi hensan iinkai (1960); Yomiuri Shinbun, February 8, 1917; Kôseishô gojûnenshi hensan iinkai (1988).

${ }^{9}$ Yomiuri Shinbun, October 26, 1923.

${ }^{10}$ Some people were critical of this event. One of the critics was Terada Torahiko (寺田寅彦, 1878-1935), a famous physicist, who condemned the "Swat the Fly Day" because he believed that it might upset the balance of nature by exterminating flies as "street sweepers" (Terada 1935). 
Fig. 2 Poster of "Swat the Fly Day" in Mie Prefecture in 1924. (Courtesy of the Ohara Institute for Social Research, Hosei University)

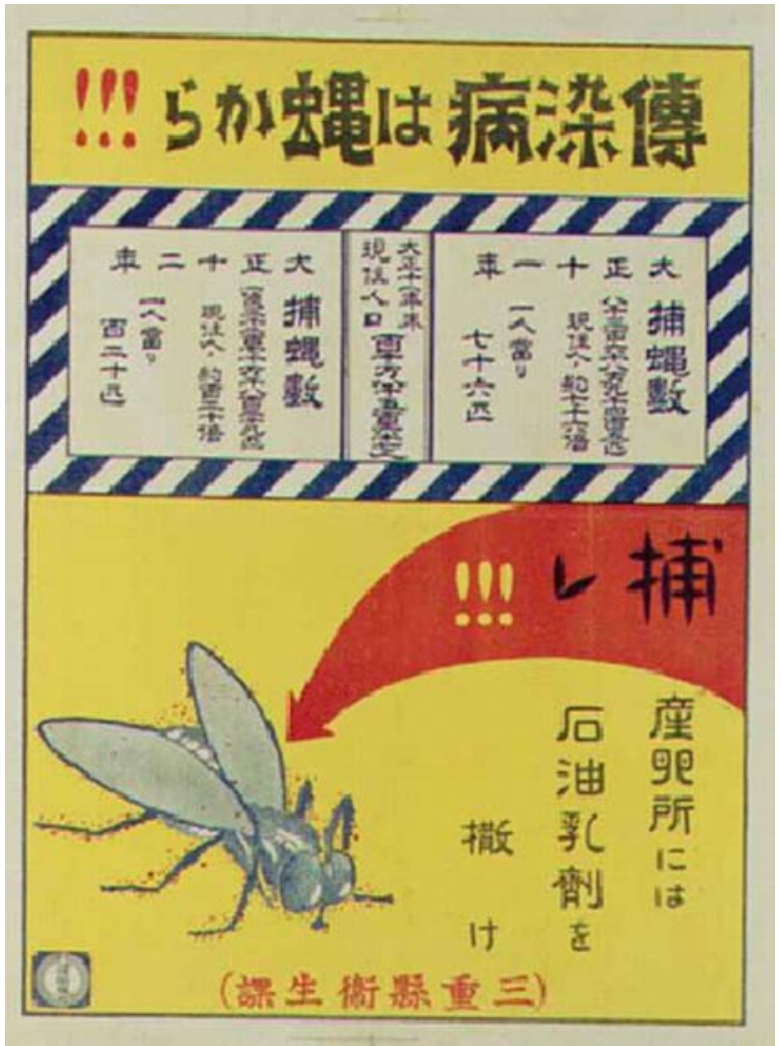

the “metropolitan public health (都市衛生, toshi eisei)," public officials organized cleanliness drives toward maintaining good health in cities.

To implement this policy, citizens were required to maintain a clean environment to help them remain healthy. Key targets in these projects were microbes. In order to mobilize people, it was necessary to make them aware that microbes were threat. Flies were a usual target for this purpose. In one of the posters for a campaign, the flies were covered with red spots, indicating microbes (Fig. 2). Flies, which had until then been looked upon as annoying but harmless creatures, began to be represented as being almost as dangerous as microbes themselves.

In addition, it is important to note that this campaign was conducted within the framework of bacteriology. Almost no entomologist or zoologist participated in this project. In those days, there were almost no medical entomologists in Japan. The exception was Yamada Shinichiro (山田信一郎, 1883-1937), an entomologist who had established the Laboratory of Sanitary Zoology at the Institute of Infectious Diseases in the University of Tokyo. ${ }^{11}$ However, he never worked on the control of flies in the metropolises, rather he was interested in the mosquito vectors of filariasis and Japanese encephalitis. He died in Shandong, China, during a field survey of the

\footnotetext{
${ }^{11}$ This institute is transferred from Kitasato's Institute of Infectious Diseases in 1914, but its members changed completely. Parasitologists such as Miyajima and those at Kitasato's institute transferred to the new Kitasato Institute.
} 
moth fly, an insect that transmits kala-azar disease. Thereafter, his laboratory work was continued by a parasitologist. ${ }^{12}$ This indicates that there was no niche for medical entomologists in the Japanese mainland in those days; however, the situation began to change in the 1940 s.

\section{The Asia Pacific War: Mobilization of Medical Zoologists and Entomologists}

It is well-known that research organizations in Japan changed radically after World War I. The Institute for Physical and Chemical Research (理化学研究所) was established in 1917, with strong support from the government and industries. In 1932, the Japan Society for the Promotion of Science (日本学術振興会) was founded to fund coordinate research between various institutes, showing that Japanese science had begun to adopt a more interdisciplinary and resourceconsuming research style (Bartholomew 1989, Chapter 7; Hiroshige 1973, Chapter3). This transformation accelerated after the outbreak of the Sino-Japanese war and particularly after the commencement of the Asia Pacific War in 1941.

However, the mobilization of scientists and engineers during the war was divided by sectionalism and was less effective than that in the United States (Grunden 2005). In the United States, the Office of Scientific Research and Development (OSRD) mobilized entomologists and found DDT as an insecticide for controlling malariatransmitting mosquitoes. On the other hand, Japanese mobilization was divided between the Army, Navy, and the Ministry of Education, all of which had different projects. As a result, Japan was unable to produce DDT until the end of the Asia Pacific War (Russell 1999; Perkins 1978). ${ }^{13}$ The Army attempted to protect their soldiers from mosquitoes; however, these efforts were unsuccessful owing to the scarcity of insecticides. More than 320,000 soldiers were infected with malaria during the war (Rikujô jieitai eisei gakkou 1971; Iijima 2005).

Although most Japanese mobilization projects were unsuccessful, the war still had a large impact on Japanese scientists. One example is that research on diseasetransmitting insects received considerable attention from the Japanese government. After the invasion and occupation of the South Pacific territories, the Japanese Army was confronted with the new problem of malaria in the battlefields and occupied areas. In Malaysia, Singapore, and the Dutch East Indies, Japan took charge of several medical colleges and institutions founded by the former colonizers. This occupation changed the framework of medical studies both in colonial Taiwan and in the Japanese mainland.

Even before the War, Taiwanese medicine had been used as a tool of imperial expansion by Japan. In the 1910s, the Government General of Formosa helped to establish Hakuai-kai (博愛会), which built several hospitals in southern China.

\footnotetext{
${ }^{12}$ A kala-azar survey by Yamada and the other members of the University of Tokyo was a part of a research project to make Chinese people more friendly with Japan, which was supported by the Ministry of Foreign Affairs. For details regarding this project, see Setoguchi (2006).

${ }^{13}$ On the relationship between war and entomology, see Russell (2001). Actually, Akitani Shichirô (秋谷 七郎), a pharmacologist at the University of Tokyo, synthesized DDT on a request from the Japanese Army. However, mass production in Japan was unsuccessful. See Kamitô (1975).

iㅡ Springer
} 
These hospitals were constructed not only for the Japanese and Taiwanese residing in China, but also for Chinese patients (Nakamura 1988, 1989, 1990, 1991). ${ }^{14}$ Although these projects focused on treatment, Taiwanese medicine during the war began to emphasize intensive research related to tropical diseases.

In 1939, the Branch of Hygiene at the Central Institute of the GovernmentGeneral of Formosa (台湾総督府中央研究所衛生部) was reorganized to become the Institute of Tropical Medicine (熱帯医学研究所) in Taihoku Imperial University, the first institute of tropical medicine in the Japanese Empire. ${ }^{15}$ In 1942, the Society of Tropical Medicine was established at Taihoku Imperial University. Tropical medicine became an important issue even on the Japanese mainland. The Japan Society for the Promotion of Science established "the Subcommittee on the Southern Medicine" in April 1942 and doctors in other Imperial Universities such as the universities of Kyoto, Osaka, and Nagoya organized workshops on "southern medicine (南方医学, nanpô igaku)" and “continental medicine (大陸医学, tairiku igaku)." In addition to the Institute of Tropical Medicine in Taiwan, the Nagasaki Medical University established the Institute of East Asian Endemic Diseases (東亜風土病研究所) in 1942, and Kyushu University attempted to set up the Institute of Tropical Medicine. Tropical medicine was institutionalized as a consequence of the mobilization for the Asia Pacific War (Anonymous 1942; Hiroshige 1973).

In this transformation, medical zoologists played an important role. They were dispatched to the South Pacific to study malaria from both parasitological and entomological perspectives. Morishita Kaoru was appointed by the Navy to investigate hygiene in New Guinea and Miyahara Hatsuo (宮原初男) was sent to Thailand in 1941 to conduct an investigation on malaria (Miyahara 1943). Ômori Nanzaburô was employed by the Army to survey the distribution and classification of Anopheles in Burma and Thailand (Morishita 1943; Ômori 1950). Both Miyahara and Ômori were members of the Laboratory of Medical Zoology, headed by Morishita.

On the other hand, on the Japanese mainland, there was different problem regarding tropical diseases. As a result of the extensive migration of people between the South Pacific and the Japanese mainland, tropical diseases were expected to gain entry into Japan. In fact, dengue fever broke out in Nagasaki, Osaka, and several other cities in the summer of 1942, infecting more than 30,000 patients (Ueno 1996). Therefore, many mainland doctors and biologists took up research on tropical diseases.

The Japanese government's process of mobilization during the war was rather complex because the Army, the Navy, and the Ministry of Education operated on independent projects. However, research teams organized by the National Research Council (学術研究会議) under the Ministry of Education in 1943 led to extensive recruitment of entomologists. In the fiscal year 1944, the National Research Council organized 195 research teams, including five teams related to insect-borne diseases. Although most of them were organized by medical professionals, it is notable that

\footnotetext{
${ }^{14}$ On Taiwanese medicine as tool of imperial expansion, see Liu (2001).

${ }^{15}$ The Government-General of Formosa established the "course of tropical medicine" at the Medical School of Taiwan in 1918, but the course was discontinued several years later.
} 
Table 1 Research teams on insect-borne diseases organized by the National Research Council

\begin{tabular}{llll}
\hline Team & Chief & Members & Budget (yen) \\
\hline $\begin{array}{l}\text { Harmful insects } \\
\begin{array}{l}\text { Prevention and treatment } \\
\text { of malaria }\end{array}\end{array}$ & $\begin{array}{l}\text { Kaburagi Tokio (University of Tokyo) } \\
\text { Tsunô Susumu (Nagasaki Medical College) }\end{array}$ & 26 & 114,500 \\
$\begin{array}{l}\text { Drugs for malaria treatment } \\
\begin{array}{l}\text { Prevention and treatment } \\
\text { of dengue fever }\end{array}\end{array}$ & Asahina Yasuhiko (University of Tokyo) & 12 & 158,000 \\
\begin{tabular}{l} 
Typhus \\
\hline
\end{tabular} & Koizumi Makoto (Keio University) & 11 & 125,000 \\
56,000 \\
\hline
\end{tabular}

Kaburagi Tokio (鏑木外岐雄, 1890-1968), an agricultural entomologist at the University of Tokyo, set up the research team on medical entomology (Table 1). ${ }^{16}$ In this project, the entomologists were ordered to explore whether there were diseasetransmitting mosquito species in the Japanese mainland, as well as mapping the distribution of Anopheles in Japan and developing insecticides to exterminate mosquitoes.

The Army and Navy also encouraged entomological research within their research institutes. Sasa Manabu (佐々学, 1916-2006), a young doctor at the Naval Medical School, visited Penang Island in Malaysia immediately after the Japanese occupation. Sasa knew from British literature that a large amount of entomological research had been undertaken on malaria. He translated these papers and dispatched them to the Naval Medical School, surprising Japanese doctors by the scale of the work. Before the war, the medical community in Japan had paid little attention to entomological research, including the taxonomy and ecology of insect vectors. However, British entomologists in Malaysia had studied the species of Anopheles mosquitoes that were vectors of malaria parasites. Based on these studies, they had conducted "species control" methods, in which the target mosquito species were exterminated. After returning to Tokyo, Sasa engaged in the taxonomy of mosquitoes at the Naval Medical School (Sasa 1985). After the war, he was employed at the Institute of Infectious Diseases in the University of Tokyo and played an important role in the development of medical entomology.

Another project set up by the Navy was the establishment of the Macassar Institute in eastern Indonesia in 1943. Although it was planned that the Institute would recruit nearly 500 employees, it was closed in May 1945 before the arrival of most of the researchers. However, Masaaki Tokunaga (徳永雅明, 1903-1998), an entomologist at Kyoto University, was engaged there in the study of the malaria vectora. ${ }^{17} \mathrm{He}$ authored the first textbook on medical entomology in Japanese in 1943 (Tokunaga 1943). Miki Shigeru (三木茂, 1901-1974), a botanist, also came to the Macassar Institute to survey the ecological habitats of mosquito vectors. In addition, Morishita Kaoru visited the Institute from Taiwan in March 1944, and gave lectures on malaria for several days (Morishita 1944). As a result, the Macassar Institute

\footnotetext{
16“"Shôwa 19 nendo gakujutsu kenkyû kaigi kenkyûhan oyobi kenkyûhi ichiran," in Gakujutsu kenkŷu kaigi kankei, Archives of the National Institute for Defense Studies, Tokyo. For the research teams organized by the National Research Council, see Nagano and Sano (1997), Sawai (2004), Aoki (2006).

${ }^{17}$ Kaku kenkyû kikan no genjô, Nanpô gakujutsu kagaku tô shokikan gôdô kankei shorui tsuduri, National Institute for Defense Studies, Archive. Also see Ôta (1991), Kurashige (1988).
} 
became an educational center for army surgeons who were dispatched to the South Pacific.

One result of the extensive recruitment of entomologists was the establishment in March 1943 of the Society of Sanitary Entomology (衛生昆虫学会) (Nomura 1958). After the war, Ômori Nanzaburo recalled the sudden emergence of medical entomology in Japan: "When I came back to Japan after the war, I was surprised to find so many researchers working on medical entomology. Most doctors, pharmacists, and entomologists who went to the war began to study malaria and Anopheles" (Japanese Society of Parasitology 1981).

The framework of research on insect-borne diseases changed radically in the 1940s because of the new agendas set by war. In Taiwan, medical zoology was expected to expand as "tropical medicine," while entomologists, who had been excluded from medical disciplines, were now able to find a niche.

\section{Concluding Remarks}

In this paper, I have discussed the manner in which the control of disease vectors changed the framework of medical research in Japan. It was in the early 1920s that control of insects arrived on a social agenda, but colonial Taiwan and metropolises had different social contexts as well as different frameworks of medical research. In colonial Taiwan, the transformation of the entire environment was planned for controlling, or even exterminating malaria-transmitting mosquitoes. In addition, medical zoology was established as a field medicine that included both parasitology and entomology. On the other hand, in the metropolises, the control of insect-borne diseases was part of the metropolitan public health program, where the collecting and controlling flies through mass mobilization was significant in ensuring a clean and healthy city. It was neither a parasitological nor an entomological project, rather a bacteriological project. After the Asia Pacific War, many entomologists entered medical research as a result of the mobilization and established a new discipline, medical entomology, with help of medical zoologists at Taihoku Imperial University.

The establishment of medical entomology changed the relationship between people and their environment after the war. Previously, most of the insect control projects had been in the metropolis. After the war, they extended to the rural areas of Japan, for example, in 1955, the Ministry of Health and Welfare decided to conduct a mass mobilization project known as the "campaign to live without mosquitoes and flies (蚊とハ工のいない生活実践運動).” Many rural citizens participated in exterminating insects, but this was not merely a mass mobilization project. Citizens were encouraged to monitor the number of insects, just like in colonial Taiwan, in the hope of transforming the whole environment to control insects (Sagawa and Hashimoto 1953). Many medical zoologists and sanitary entomologists were engaged in this project.

As a result, both the mobilization of citizens and transformation of environment became possible in Japan. The relationship between the people and diseasetransmitting insects after World War II in Japan was transformed by field medicine in colonial Taiwan, public health in metropolises, and the mobilization of entomologists during the war. 


\section{References}

Anonymous. (1942). Nettai igaku kai jiji. Nettai igaku, 1, 163-164.

Aoki, H. (2006). Dai 2 ji sekai taisen chû no kagaku dôin to gakujutsu kenkyû kaigi no kenkyû han. Shakai keizai shigaku, 72, 331-353.

Bartholomew, J. R. (1989). The formation of science in Japan. New Haven: Yale University Press.

Bird, I. L. (1880). Unbeaten tracks in Japan (Vol. 1, pp 154-155, 213). London: John Murray.

Chu, Y. (2005). Taiwan kunchongxue shi hua (pp. 231-247). Taipei: Yushanshe.

Evans, H. (1989). European malaria policy in the 1920s and 1930s: The epidemiology of minutiae. Isis, 80, 40-59.

Farley, J. (1992). Parasites and the germ theory of disease. In C. E. Rosenberg \& J. Golden (Eds.), Framing disease: Studies in cultural history (pp. 33-49). New Brunswick, NJ: Rutgers University Press.

Fukami, T. (1931). Tsuzuki Dokutoru Yoei (pp. 144-147). Tokyo: Mainichi shinbunsha shuppanbu.

Geong, H. (2001). Carving a niche for medical entomology: A quest for professional identity in American entomology. American Entomologist, 47, 236-243.

Grunden, W. E. (2005). Secret weapons and World War II: Japan in the shadow of big science. Lawrence: University Press of Kansas.

Hiroshige, T. (1973). Kagaku no shakaishi (pp. 200-203). Tokyo: Chûôkôronsha.

Howard, L. O. (1912). The house fly: Disease carrier. London: John Murray.

Iijima, W. (2005). Mararia to teikoku (pp. 35, 208-217). Tokyo: Tokyo University Press.

Japanese Society of Parasitology (Ed.) (1981). Kiseichû gakkai gojû nen no ayumi (p. 84). Tokyo: Japanese Society of Parasitology.

Kamitô, A. (1975). DDT, BHC, parachion ga yo ni deru made. Nihon nôyaku gakkai shi, 0, 21.

Keishichô shi hensan iinkai (Ed.) (1960). Keishichô shi Taishô hen (pp. 715-716). Tokyo: Keishichô shi hensan iinkai.

Koizumi, M. (1921). Taiwan ni okeru kazoku no yobô igaku teki kenkyû. Taihoku: Kôbunkan.

Koizumi, M. (1928). Taiwan ni okeru mararia bôatsu sagyô ni kansuru shaken narabini teian. Taiwan igakukai zasshi, 275, 109-131, 117, 121.

Kôseishô gojûnenshi hensan iinkai (Ed.) (1988). Kôseishô gojûnenshi kijutsuhen (pp. 233-234). Tokyo: Kôsei mondai kenkyukai.

$\mathrm{Ku}$, Y. (2004). Anti-parasite vs. anti-mosquito-anti-malaria program in colonial Taiwan. Taiwan Historical Research, 11, 185-222.

Kurashige, Y. (1988). Ranin taizai ki (pp. 40-42). Tokyo: Shimizu kôbundô.

Li, S. J. (2002). Natural history of parasitic disease: Patrick Manson's philosophical method. Isis, 93, 206-228.

Liu, S. (2001). Taiwan ni okeru shokuminchi igakuno keisei to sono tokushitsu. In M. Miichi, et al. (Eds.), Shippei, kaihatsu, teikokuiryô (pp. 237-267). Tokyo: University of Tokyo Press.

Marlatt, C. L. (1953). An entomologist's quest: The story of the San Jose scale (pp. 132-133). Baltimore: Monumental Printing.

McClary, A. (1982). A corner history: "Swat the fly": Popular magazines and the anti-fly campaign. Preventive Medicine, 11, 373-378.

Miyahara, H. (1943). Tai koku no chôsa wo owarite. Taiwan no ikai, 2, 83-96.

Miyajima, M. (1943). Nanpô keiron to kôsei mondai. Kyoto: Jinbun shoin.

Morishita, K. (1943). New Guinea jijô. Shinpo, 8, 1-25.

Morishita, K. (1944). Mararia tokubetsu kôen. Division of tropical hygiene, Macassar Institute.

Morishita, K. (1976). Mararia no ekigaku to yobô (pp. 116-124). Tokyo: Kikuya shobô.

Morishita, K. (1988). Koizumi Makoto. In H. Kihara, et al. (Eds.), Kindai Nihon Seibutsugakusha Shôden (pp. 343-349). Tokyo: Hirakawa Shuppansha.

Morishita Kaoru kyôju taikan kinen jigyô jikkô iinkai (Ed.) (1961). Morishita Kaoru kyôju taikan kinenshi. Osaka: Morishita Kaoru kyôju taikan kinen jigyô jikkô iinkai.

Morse, E. S. (1917). Japan day by day (Vol. 1, p. 87). Boston, New York: Houghton Mifflin.

Nagano, H., \& Sano, K. (1997). Gakujutsu kenkyû kaigi dai 1 bu no senji kenkyû han. Kagakushi Kenkyû, II-26, 162-168.

Nakamura, T. (1988). Amoi oyobi Fukushû hakuaikai iin no setsuritsu. Nanpô bunka, 15, 1-57.

Nakamura, T. (1989). Sentô hakuaikai iin no setsuritsu. Tenri daigaku gakuhô, 162, 15-28.

Nakamura, T. (1990). Kanton Hakuaikai iin wo meguru shomondai (1). Tenri daigaku gakuhô, 165, $25-49$. 
Nakamura, T. (1991). Kanton Hakuaikai iin wo meguru shomondai (2). Tenri daigaku gakuhô, 166, 1-24. Narita, R. (2003). Kindai toshi kûkan no bunka taiken (pp. 15-28). Tokyo: Iwanami shoten.

Nawa, Y. (1899). Konchû to eisei tono kankei. Chûo Igakukai Zasshi, $38,15$.

Nomura, K. (1958). Honkai setsuritsu no koto domo. Eisei dôbutsu, 9, 1-4.

Oda, T. (1974). Taiwan igaku gojûnen (p. 32). Tokyo: Igakushoin.

Ômori, N. (1950). Anopheles no bunpu ni tsuite. Eisei dôbutsu, 1, 1.

Osaka fu eiseikai. (1992). Osaka eisei hyakunenshi (pp. 430-434). Osaka: Osaka fu eiseikai.

Ôta, K. (1991). Kaigun gunsei chiiki ni atta Macassar kenkyûjo. Seiji Keizai sigaku, 300, 61-80.

Perkins, J. H. (1978). Reshaping technology in wartime: The effect of military goals on entomological research and insect-control practices. Technology and Culture, 19, 169-186.

Rikujô jieitai eisei gakkou (Ed.) (1971). Daitôasensou rikugun eiseishi 1 (pp. 576-577). Tokyo: Rikujô jieitai eiseigakkou.

Rogers, N. (1989). Germs with legs: Flies, disease, and the new public health. Bulletin of History of Medicine, 63, 599-617.

Russell, E. P. (1999). The strange career of DDT. Technology and Culture, 40, 770-798.

Russell, E. (2001). War and nature: Fighting humans and insects with chemicals from World War I to silent spring. Cambridge: Cambridge University Press.

Sugawa, Y., \& Hashimoto, M. (1953). Ka to hae no inai seikatsu, Tokyo: Nihon kôshûeisei kyôkai.

Sasa, M. (1985). Shizen koso waga shi (pp. 22-31). Tokyo: University of Tokyo Press.

Sawai, M. (2004). Senjiki Nihon no kenkyû kaihatsu taisei. Osaka daigaku keizaigaku, 54, 383-409.

Setoguchi, A. (2004). Gaichû kan no kindai. In T. Ueda (Ed.), Tonbo to Shizenkan (pp. 286-306). Kyoto: Kyoto University Press.

Setoguchi, A. (2006). Igaku, kiseichûgaku, konchûgaku. Kagakutetsugaku kagakushi kenkŷ̂, 1, $125-138$.

Shiraki, T. (1969). Omoi dasu mama ni (pp. 43-44). Kodaira: Shiraki Tokuishi sensei beiju kinen shukuga jigyôkai.

Taiwan sôtokufu keimu kyoku eisei ka. (1932). Mararia Bôatsu shi (Vol. 79, pp. 127-132). Taihoku: Taiwan sôtokufu keimu kyoku eisei ka.

Terada, T. (1935). Jiyû gakô. Chûô kôron, 568, 219-227.

Tilley, H. (2004). Ecologies of complexity: Tropical environments, African trypanosomiasis, and the science of disease control in British Colonial Africa, 1900-1940. Osiris, 19, 21-38.

Tokunaga, M. (1943). Iyô konchû gaku. Tokyo: Shinryo to Keiken sha.

Tsutsumi, M. (1928). Hae to jinsei (pp. 32-38). Tokyo: Kinshôdo shoten.

Tsuzuki, J. (1902). Mararia Shinsetsu (pp. 212-220). Tokyo: Published by Tsuzuki.

Tsuzuki, J. (1903). Meiji 35 nen Hokushin no ryûkyô ni okeru korera ryûkyô oyobi bôatsu ni kakawaru fukumeisho (1). Rikugun gunikai zasshi, 135, 292-316, 310.

Tsuzuki, J. (1904). Bericht über meine epidemiologischen Beobachtungen und Forschungen wärend der Choleraepidemie in Nordchina im Jahre 1902 und über die im Verlaufe derselben von mir dürchgeführten prophylaktischen Massregeln mit besonder Brücksichtigung der Choleraschutzimpfung. Archiv für Schiffs und Tropenhygiene, 8, 71-81.

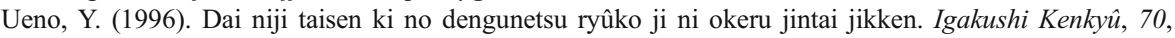
$356-364$.

Wakimura, K. (2002). Kikin, sippei, shokuminchi tôchi (pp. 229-328). Nagoya: Nagoya University Press.

Worboys, M. (1976). The emergence of tropical medicine: A study in the establishment of a scientific specialty. In G. Lemaine, R. MacLeod, M. Mulkay, \& P. Weingart (Eds.), Perspectives on the emergence of scientific disciplines (pp. 75-98). Chicago: Aldine.

Worboys, M. (1988). Manson, ross and colonial medical policy: Tropical medicine in London and Liverpool, 1899-1914. In R. Macleod \& M. Lewis (Eds.), Disease, medicine and empire: Perspectives on western medicine and the experience of European expansion (pp. 21-37). London: Routledge.

Worboys, M. (1993). Tropical diseases. In W. F. Bynum \& R. Porter (Eds.), Companion encyclopedia of the history of medicine (Vol. 1, pp. 512-536). London: Rutledge.

Worboys, M. (1996). Germs, malaria and the invention of mansonian tropical medicine: From "diseases in the tropics" to "tropical diseases". In D. Arnold (Ed.), Warm climates and western medicine: The emergence of tropical medicine, 1500-1900 (pp. 181-207). Amsterdam: Recopy. 